DOI https://doi.org/10.30525/978-9934-26-039-1-36

\title{
РОЛЬ САРКАЗМУ В РЕАЛІЗАЦІЇ КОМІЧНОГО (НА МАТЕРІАЛІ ХУДОЖНЬОЇ АНГЛОМОВНОЇ ПРОЗИ)
}

\author{
Блинова I. A. \\ кандидат філологічних наук, доцент, \\ завідувач кафедри іноземних мов за професійним спрямуванням \\ Національний педагогічний університет імені М. П. Драгоманова
}

\section{Зернецька А. А.}

доктор філологічних наук, професор, декан факультету іноземної філології

Національний педагогічний університет імені М. П. Драгоманова м. Київ, Україна

Сарказм виступає одним із змістовних різновидів категорії комічного і входить до складу іï традиційної парадигми, в якій, як правило, виокремлюються поняття «гумор», «іронія», «сатира», «чорний гумор». Сучасні вітчизняні й зарубіжні мовно-та літературознавчі джерела довідкового характеру містять наступні тлумачення сарказму, а саме: сарказм (грец. sarkasmos - терзання) - їдка, викривальна, особливо дошкульна насмішка, сповнена крайньої ненависті і гнівного презирства [4, с. 611]; вид комічного; судження, що містить їдку, уїдливу насмішку над зображуваним, вищий ступінь іронії [3, с. 934]; sarcasm - a way of using words that are the opposite of what you mean in order to be unpleasant to somebody or to make fun of them [8]. Як бачимо, спільною ознакою поданих тлумачень $є$ неприємний, жорсткий і різкий характер висловлювань-осміювань. Отже, під сарказмом розуміється різновид комічного, що відбивається в ядовитій, злій насмішці, яка викриває явища особливо безпечні своїми суспільними наслідками.

У мовленнєвому вираженні сарказм, як правило, призначений для того, щоб завдати болю або поранити, зробити свою жертву предметом глузування; викрити певне явище через знущання: «sarcasm applies chiefly to a savage, bitter form of humor intended to cut or wound; sarcasm need not imply the use of verbal irony, sometimes suggesting no more than plain speaking, but it regularly implies as its aim the intent to make the victim an object of ridicule» [10, c. 877].

Охарактеризуємо досліджуване поняття, послуговуючись естетичними, соціальними, біопсихологічними і лінгвістичними 
критеріями розмежування різновидів комічного, запропоновані А. О. Бєляковим [1, с. 94-95]. Сарказм не має подвійного, часто прихованого, семантичного дна, а виражається завжди прямо. Йому притаманне поєднання гніву, ненависті з гіркою посмішкою. При цьому смисл сарказму не вичерпується більш високим ступенем глузування, викриття, але полягає перш за все в особливому співвідношенні двох планів: у сарказмі іносказання нарочито послаблюється або знімається. Негативну, нищівну оцінку сарказм нерідко відкрито оголює в самому тексті, слідом за видимим вихвалянням. Сарказму не властиво «спокійне» ставлення до предмета зображення або «гра» 3 ним. Навпаки, його відрізняє тон обурення, роздратування, гніву.

Об'єктом саркастичного осміяння виступають речі небезпечні, різко негативні й аморальні - соціальні вади, явища, особливо небезпечні суспільними наслідками. Сарказм різниться від інших видів комічного дуже високим ступенем злободенності і критичності. Крім цього, актуалізація сарказму може бути пов'язана з типологією й ідеологією політиків. Жорстке несприйняття суспільних норм проявляється в дуже сильній вербальній агресії і пояснює негативний характер оцінного знаку. Сутність сарказму полягає в підкреслено посиленому контрасті того, що мається на увазі (підтексту), і того, що виражається (зовнішнього смислу): явищу, що осміюється, спочатку приписується позитивна якість, потім одразу ж заперечується [5, с. 305-306].

У сарказмі головне - крайній ступінь емоційного відношення i вираження, високий пафос заперечення, що переходить у обурення [2, с. 165], доходить до межі з цинізмом, тобто нахабним, безсоромним ставленням до норм суспільної моралі, моральності, які припускають абсолютну цінність власного «Я». Характер вираження саркастичної оцінки переважно експліцитний. Завдяки середньому ступеню інтелектуальності, ступінь розуміння комічного адресатом достатньо високий. Саркастичний перлокутивний ефект проявляється в обуреному сміху, «пекельному» реготі.

На думку Е. Кемп, сарказм передбачає уніфіковану операцію смислової інверсії, що виявляється по-різному чотирма підвидами сарказму [6, с. 586-634]. Усі чотири різновиди інвертують те, що мовець припускає або робить вигляд, що припускає (або передбачає те, що мав на увазі хтось інший), відносно до викликаної нормативної шкали. Ціль сарказму та результат інверсії широко варіюються залежно від виду. Пропозиційний (propositional) сарказм функціонує найбільш часто як традиційна модель, надаючи імплікацію, яка суперечить твердженню, що було б виражене істинним висловленням. Лексичний (lexical) сарказм надає інвертовану композиційну цінність для одного виразу чи 144 
фрази. Сарказм з префіксом like (like-prefixed) зобов'язує мовця до відвертого епістемічного заперечення основного змісту декларативного висловлювання. I нарешті ілокутивний (illocutionary) сарказм виражає відношення/ставлення протилежне до того, яке б виражалося істинним висловлюванням.

Сарказм часто використовує невербальні засоби - інтонацію, міміку, жести - в якості натяку чи сигналу, перифраз, інверсію та інші лінгвістичні засоби для створення комічного ефекту. Одним з композиційних прийомів утворення сарказму є паралелізм того, що мається на увазі, і того, що виражається. За допомогою перифрази сарказм реалізується таким чином: у відоме всім літературне джерело вкладається новий викривальний зміст. Співставлення в свідомості читача/слухача раніше відомого образу з новоствореним викликає за контрастом необхідний комічний ефект. Різкість заперечення в сарказмі часто пов'язують із вживанням наказового способу дієслів.

Також зарубіжними лінгвістами [7, с. 148-180] при вивченні проявів сарказму (зокрема і в художній літературі) розглянуті типові синтаксичні структури, названі як розщеплені $w h$-запитання (Split Interrogative) типу Who are you, Dr. Kevorkian?; What is this, the Wild West? Вони описані вченими як двосторонні розмовні формули з компонентами основної частини і пропозиції: wе can describe the Split Interrogative as a bipartite conversational formula composed of a WH-interrogative - the body, e.g. What is this, followed by tag-position guess - the proffer bearing polar-interrogative intonation, the Wild West. Пропозиція може виражатися підрядним реченням або іменною, прикметниковою, прийменниковою, прислівниковою фразою. Розщеплене $w h$-запитання коментує поточну ефективність, індексуючи зусилля користувача прив'язати правильне значення до належної змінної в контекстуально вираженій відкритій пропозиції і пропонуючи результат цих зусиль.

Зауважимо, що вказаний лінгвістичний засіб $\epsilon$ широко вживаним у творчості К. Воннегута, одного 3 найбільш значних прозаїків американської літератури XX-го століття. Так, наведені нижче приклади свідчать про високу частотність вживання зазначеної моделі саркастичного світовідбиття автором: "I'll tell the world! And what have I been doing for the past year? Slaving to work out a light bulb so dogs can play at night!» [9, c. 58]; But what was it that was worth more to Herbert than eight hundred and fifty thousand? Binges? Dope? Women? [9, c. 39]; My mother isn't mentioned, but what she taught me to say in place of ain't I? or aren't I? or amn't I? was am I not? Speed isn't everything. [9, c. 59]; but where are the leaders this time? All you have is a lot of ordinary people standing around with their thumbs up their ass [9, c. 179]; «And what am I supposed 
to say - that you're stunningly handsome? That I feel an overwhelming desire to throw myself into your manly arms?» [9, c. 27]; What was in the needle, honey bunch? Why, honey bunch, they call that 'truth serum'. [9, c. 26]; «Why keep your wife in suspense, Colonel?» said Pi Ying. «Be a good husband and answer her question, or should I?» [9, c. 52]. Парадоксальність інформації, закладеної в другій частині висловлювання - пропозиції, що проявляється в ііі співвідношенні з першою, дозволяє інтерпретувати єдине в смисловому відношенні висловлювання як саркастичне. Пропозиційний сарказм у цьому випадку передбачає заперечення певної пропозиції, пов'язаної з тим, що стверджується / запитується / упорядковується чи має місце. Завдяки переходу від позитивної до протилежної за змістом оцінки об'єкта у виділених синтаксичних структурах письменник вказує здебільшого на недоліки героїв, їх негативні дії, думки, поведінку.

\section{Література:}

1. Беляков А. А. Объем и содержание категории комического. Стереотипь лингвокультуры: коллективная монография / [отв. ред. М. В. Пименова]. К.: Изд-ий дом Д. Бураго, 2013. С. 90-103.

2. Литература: Справочные материалы: кн. для учащихся / С. В. Тураев, Л. И. Тимофеев, К. Д. Вишневский и др. М.: Просвещение, 1989. $335 \mathrm{c}$.

3. Литературная энциклопедия терминов и понятий / [под ред. А. Н. Николюкина]. М.: НПК «Интелвак», 2001. 1600 стб.

4. Літературознавчий словник-довідник / [за ред. Р. Т. Гром'яка, Ю. І. Ковалів, В. І. Теремка]. К.: ВЦ «Академія», 2007. 752 с.

5. Эстетика: словарь / [под. ред. А. А. Беляева и др.]. М. Политиздат, 1989. $447 \mathrm{c}$.

6. Camp E. Sarcasm, Pretense, and The Semantics / Pragmatics Distinction. In: Noûs 46.4, 2012. pp. 587-634.

7. Michaelis L. A., Feng H. What is this, sarcastic syntax? Constructions and Frames. 7(2). 2015. pp. 148-180.

8. Sarcasm. Oxford Learner's Dictionaries URL: https://www.oxfordlearnersdictionaries.com/definition/english/sarcasm? q=sarcasm (дата звернення: 12.02.2021).

9. Vonnegut K. Palm Sunday. Welcome to the Monkey House. Random House UK, 1994. 672 p.

10. Webster's New Dictionary of Synonyms / [ed. By Ph. B. Gove]. Springfield, Massachusetts: Merriam-Webster Inc., 1984. 909 p. 